\title{
THE INFLUENCE OF VOLUNTARY GLOBAL REPORTING INITIATIVE (GRI) ON THE PERFORMANCE OF INDONESIA LISTED COMPANIES
}

\author{
Hurian Kamela*1), Ryan Saputra Alam²) \\ Pascasarjana Ilmu Akuntansi, Universitas Indonesia ${ }^{1)}$, Pascasarjana Manajemen Sumber Daya \\ Manusia, Universitas Indonesia ${ }^{2)}$ \\ melakame193@gmail.com ${ }^{l)}$,rysalamilmi@gmail.com ${ }^{2}$
}

\begin{abstract}
The background of this research is Indonesian companies are still voluntarily using GRI compare to other countries' cases. The main thing is that the limited number of companies that use GRI can affect its performance. The organization's performance describes the company's financial ratios as one of the effective financial performance descriptions. This is related to economic factors that are internal to the company, such as GRI, CSR, and ESG. The purpose of this study was discussed because of the limited number of listed companies in Indonesia (listed in IDX) using the GRI G4 method globally, which is one of the highlights of this research. The data used for 4 years, namely 2016-2019 in Indonesia. This research methodology uses panel data regression. This study uses secondary data, namely from the company's financial statements and database streams (Thomson Reuters Eikon). The results of the study prove that GRI affects financial ratios. The same result also occurs in other variables, namely ESG affects financial ratios (ROA). The controversy is that companies that have been listed must pay more attention to developments in items in GRI to gain trust from foreign investors and confidence in the company's sustainability.
\end{abstract}

Keywords : GRI, CSR, ESG, Indonesia

*Corresponding author

Email:melakamel93@gmail.com

DOI: https://doi.org/10.33369/j.akuntansi.11.1.16-22

\section{INTRODUCTION}

Triple Bottom Line (Economic, Social, and Environmental) describes an effective firm organization. The adoption of the Global Reporting Initiative (GRI) which has certain standards in indicators, especially from financial reports provides evidence that the implementation of GRI should be done globally (worldwide). However, its implementation in Indonesia is still limited, only a few companies have implemented GRI regulations because it is not mandatory in Indonesia, only large companies have provided an assessment of GRI. This case is strongly supported by Fuente (2017) discussing that GRI is one of the effective disclosure systems in the development of companies globally, if the indicators regarding GRI have been applied it might have a large influence on the development of performance for the better. This also relates to the implementation of Corporate Social Responsibility (CSR) as an early indicator of the effectiveness of the GRI-G4 implementation because it covers the social aspects of the company's development.

CSR is one of the aspects related to the environment and society. registered companies must implement CSR for the sake of company sustainability goals which is not just for profit, but also must increase the sustainability of the company in terms of investors and stakeholder's trust. Mishra \& Suar's (2010) explained that CSR affects the company's financial performance, which proves that CSR is a crucial part in terms of increasing company performance, especially quality improvement. The study of Lambooy (2010) and Forte (2013) also describes CSR roles on the company, the better of organizing the CSR, also means strong financial performance, also it means the company has some responsibility against an environment that signed as a reputable company. Nonetheless, there is still limited research that links the comparison 
between CSR, GRI, and other economic factors. CSR has long been adopted by companies because every company is obliged to publish its activities based on the interests of the community.

Similar to the above explanation, the implementation of ESG (environmental, social, government) is an indicator in the realization of a green economy implementation that is the same level as GRI and CSR. since ESG information is related to company value (company performance) which may influence business decisions. The application of ESG also still has positive effects on ESG, one of which was Oikonomou et al. (2012) stated that virtuous social performance implementation may increase company value by reducing special costs and risks. This could increase the company's total reputation consequently that the company has a low risk of bankruptcy.

The reason behind this study was since the only big firm company that uses GRI. GRI aspects are relatively small since most companies are still evaluating the appropriate implementation, strategies that are appropriate to the economy in Indonesia, for example, company profits are donated for the benefit of the environment, when waste is handled (including one of the social factors). Companies must implement appropriate and effective policies to overcome these problems, such as making provisions for profits for the benefit of the environment. This profit allowance can reduce the company's net income. This is closely related to financial ratios, namely Return On Assets (ROA) regarding the use of financial resources owned by the company.

\section{RESEARCH METHODS}

\section{Global Reporting Initiative (GRI)}

Global Reporting Initiative (GRI) is one of the reports issued by the GRI Standards in 2000 on economic, environmental, and social-based reporting. This relates to the sustainability of the company, organization, and implementation related to the sustainability of areas based on standard stages, consisting of 4 units (G4), namely GRI 101, GRI 200, GRI 300, GRI 400. This report was developed for more than 90 countries that adopted reporting based on the guidelines of the Sustainability Reporting Standards. Topics developed from the GRI Standards include 3 universal standards such as points for using GRI Standards, information reporting, and management approaches. The next development, GRI points were developed into 33 specific rules covering economic, environmental, and social series (GRI Standards, 2016).

The basis for using GRI in Indonesia is still voluntary, companies can report financial reports in general or add additional reports that include not only financial but environmental based. In Indonesia, companies that make disclosures based on point 33 of the GRI rules are still limited. Based on the Thomson Reuters database system (2020), only 35 companies in Indonesia that have been listed on the Indonesia Stock Exchange (IDX) have complete data on the GRI score, because companies that disclose the GRI score are still limited to large-scale companies (companies that have high funding, assets, and income). Fuente's (2017) research explains that the adoption of a structured GRI is a level development of the harmonization of financial statements around the world because it has the same standards and basis. GRI is one of the main points in the development of a company that is not only looking for profit but can develop the environment for the future. 


\section{G4 Objectives}

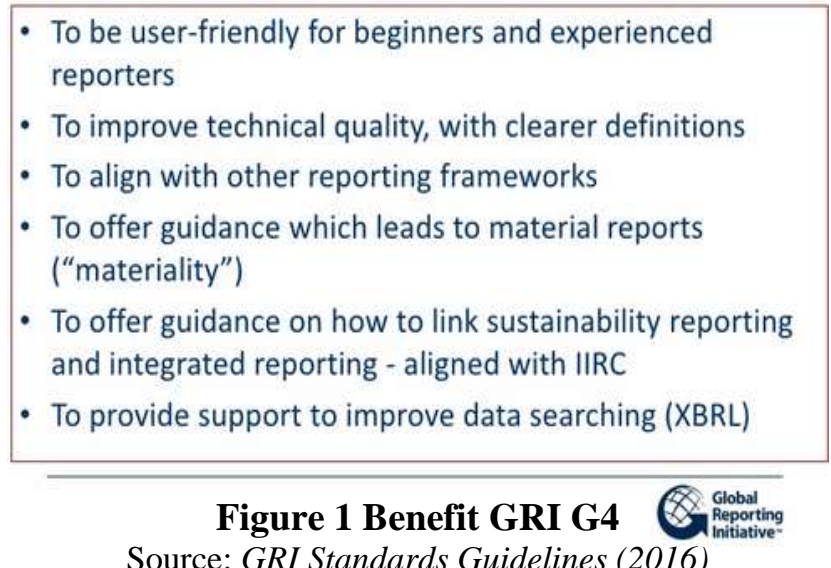

Figure 1 describes the benefits of implementing GRI based on the GRI Standards Guidelines (2016), including: (1) easy to understand, (2) improving quality, (3) adjusting to other reporting frameworks, (4) regulating report material, (5) as a tool for connecting sustainability and integrated reporting, (6) providing an online information search data source (XBRL).

\section{Corporate Social Responsibility (CSR)}

Corporate Social Responsibility (CSR) is one of the most researched aspects of accounting development because CSR is related to financial reports that describe the company's productivity in making use of finance for social interests. Gamerschlag et al. (2011) who researched in Germany explained that CSR refers to the company's contribution in developing a sustainable company, especially in contributing to media campaigns and activities that increasingly provide benefits to the company. Portney (2008) explains that companies run CSR based on 6 reasons, namely (1) finding potential consumers, (2) increasing employee loyalty and increasing productivity, (3) getting investors, (4) providing effective relationships to policymakers, (5) improve relations with subordinates (bottom line). Skare \& Golja (2013) provide evidence regarding the relationship between CSR in 25 countries with economic growth variables that CSR has a positive effect on economic growth, especially in countries that have used effective CSR standardization, countries that do not have optimal CSR guidelines and less than optimal implementation. It will be difficult to increase good economic performance, this explains that there is a need for synergy between companies that comply with CSR and policies that have been made by the government so that economic growth will get better performance.

\section{Environmental Social Governance (ESG)}

Sassen et al. (2016) researched ESG performance, that ESG is information that discusses the main pillars consisting of governance, economic, and social. This can be displayed in companies that have disclosed it specifically in the form of scores that have been summarized in a specific database (Thomson Reuters Eikon). This illustrates that one of the roles of ESG includes environmental assessment. ESG score describes the number of ESG value calculations for each company, useful for measuring company risk. 
THE INFLUENCE OF VOLUNTARY GLOBAL REPORTING INITIATIVE (GRI) ON THE PERFORMANCE OF INDONESIA LISTED COMPANIES

Hurian Kamela dan Ryan Saputra Alam

Table 1 Measurement

\begin{tabular}{|c|c|c|}
\hline Variable & & Measurement \\
\hline GRI & Global Reporting Initiative (GRI) & $\begin{array}{c}\text { GRI Guidelines Score (Datastream } \\
\text { Thomson Reuters Eikon). }\end{array}$ \\
\hline CSR_SUS & CSR Sustainability & $\begin{array}{l}1=\text { Sustainability disclosure, } 0=\text { not } \\
\text { conducted Sustainability disclosure } \\
\text { (Dummy Score 1-0). }\end{array}$ \\
\hline ESG & Environmental Social Governance & $\begin{array}{c}\text { ESG Score (Datastream Thomson } \\
\text { Reuters Eikon) }\end{array}$ \\
\hline ROA & Return On Assets & $\begin{array}{c}\text { ROA = Net Income / Average } \\
\text { Assets }\end{array}$ \\
\hline
\end{tabular}

Source: Data collected, 2020

Table 1 describes the details of the measurements used in this study consisting of GRI, CSR_SUS, ESG, and ROA using secondary data for 4 years during 2016-2019 using data regression (Stata version 14).

Table 2 Sample

\begin{tabular}{lc}
\hline \multicolumn{1}{c}{ Remark } \\
\hline $\begin{array}{l}\text { Numbers of Company implemented GRI-4 In } \\
\text { Indonesia }\end{array}$ \\
\hline The company did not have complete data \\
$\begin{array}{lc} \\
\text { The company has complete data (ESG, CSR, GRI } \\
\text { score di database stream) and Financial Report. }\end{array}$ \\
\hline Total Sample used & 35 \\
\hline Total Observation (35x4 Year) & 35 \\
\hline Source: Data collected, 2020 &
\end{tabular}

Table 2 describes the research samples taken from as many as 35 companies and overall observations of 140 observations. This study uses secondary data. The data used was from 4 years during 2016-2019 with a sample of 11 companies that have implemented GRI, CSR, ESG in Indonesia.

The theory used in this research is the stakeholder theory. The theory is based on Fleege \& Adrian (2004) this theory discusses other parties who have differences other than outside parties, namely shareholders who are interested in developments about the company (especially information). This theory is based on the corporation not only to be accountable to the shareholders but also other parties respectively, either individually or in groups, who can influence future decisions and actions. Greening (1994) relates that the implementation of environmental-based activities of Corporate Social Responsibility (CSR) can be long-term (longterm) when directors implement CSR. The implementation of management regarding CSR can provide certainty and anticipation of risk accordingly that between shareholders and stakeholders can be assured (Martínez-Ferrero and Frías-Aceituno, 2013).

Previous research from Garcia (2013) regarding the effect of the GRI Guidelines, increased transparency, namely disclosure (sustainability disclosure). This explains that there is a positive influence on the GRI Standards rules implemented by regulators, especially in the adoption of GRI because it can increase stakeholder transparency and increase the capacity of the Board of Directors related to company sustainability. Previous research on ROA has also been conducted by Syahnaz (2013) which discussed CSR has a positive effect on ROA. Angelia \& Suryaningsih (2015) explain that Environmental performance and Corporate Social Responsibility (CSR) have a positive effect on ROA. The hypothesis taken is: 
$H_{1}$ : GRI positively influence ROA

$\mathrm{ROA}_{i t}=\alpha_{\mathrm{it}}+\beta 1 \mathrm{GRI}_{\mathrm{it}}+\beta 2 \mathrm{CSR} \_\mathrm{SUS}$ it ee $+\beta 3 \mathrm{ESG}$ it $+\varepsilon_{i t .}$

\section{RESULTS AND DISCUSSION}

Table 3 describes the descriptive statistics of this study. The dependent variable, with ROA, has a mean value of $9.8 \%$ and a minimum score of $-5 \%$ as well as a maximum of $46.1 \%$. The independent variable, the GRI score, has a mean value of 35.52 with a minimum of 0 and a maximum of 75.71. The control variable in this study, namely CSR_SUS, uses a dummy measurement (1-0) with an average mean of $67.85 \%$ with a minimum score of 0 and a maximum of 1 . Another control variable was the ESG score with the score obtained from the data stream. it has a mean of 40.46, and 0 (minimum), and 82.12 (maximum).

Table 3. Statistic Description

\begin{tabular}{lccccc}
\hline \multicolumn{1}{c}{ Variable } & $\mathrm{N}$ & Mean & Dev Std & Min & Max \\
\hline ROA & 140 & .0985998 & .0981768 & -.057873 & .4617435 \\
\hline GRI & 140 & 35.5235 & 37.22879 & 0 & 75.71 \\
\hline CSR_SUS & 140 & .6785714 & .4687018 & 0 & 1 \\
\hline ESG & 140 & 40.46243 & 20.27589 & 0 & 82.12
\end{tabular}

Source: Data processed, 2020

Table 4 describes the regression results of this study. GRI has a positive probability value of 0.003 with a coefficient of -.0008989 , the result explains that the application of GRI has a positive effect on ROA.

Table 4. Result

\begin{tabular}{cccccc}
\hline Variable & Hypoteses & Coef & t-stat & Prob & Sign. \\
\hline Cons & & .0610365 & 3.38 & 0.001 & \\
\hline GRI & $(+)$ & -.0008989 & -3.06 & 0.003 & $* * *$ \\
\hline CSR_SUS & & -.0326561 & -1.47 & 0.143 & \\
\hline ESG & & .0022652 & 4.83 & 0.000 & \\
\hline
\end{tabular}

$N=140, R 2=0.1746, F-$ Stat $=9.59$, Prob $>F=0.000$

Source: Data processed, 2020

The study has the same result as the research from Garcia (2013) that GRI influences the company's financial performance. This provides evidence that the higher the application of the GRI following the Guidelines Standard will improve financial performance in ROA. Companies that have implemented GRI points and have complied with the GRI rules can enhance the company's reputation for being sustainable. The results analysis also explains that although the number of companies in Indonesia that have complete data according to GRI is only 35 companies, the results of this study could prove the role of GRI in the company's asset ratio. The control variables such as CSR_SUS give different results, particularly a probability of 0.143 , namely $>0.05$ that there is no influence of CSR on ROA, this can happen because CSR is not the main focus of companies that have implemented Standard Guidelines, because in the GRI companies that have adopted GRI must have done CSR before, so a GRI-based report must contain elements in CSR, especially regarding social and environmental issues. 
Another control variable, namely ESG, gives positive results, that the higher the ESG will affect ROA with a probability value of 0.000 , namely $<0.05$, this explains that ESG does have the same basis regarding environmental, social, and corporate governance because the company Those who have applied the ESG score disclose the GRI score based on the pillars in the Guidelines.

Table 5. VIF

\begin{tabular}{|c|c|}
\hline Variable & VIF \\
\hline GRI & 2.05 \\
\hline CSR_SUS & 1.84 \\
\hline ESG & 1.54 \\
\hline Mean VIF & 1.81 \\
\hline
\end{tabular}

Table 5 describes the presence or absence of multicollinearity in this study. VIF score was considered fit if it has a score below 10. The results of table 5 give an average (mean) of 1.81. The highest VIF is GRI of 2.05 and the lowest is ESG of 1.54. The result of this study does not engage a multicollinearity problem.

\section{CONCLUSIONS AND SUGGESTION}

This study discusses the relationship between GRI and the company's profitability ratio, in other words, Return on Assets (ROA). The results of this study provide evidence that GRI affects performance ratios. The same result also occurs in the control variable, particularly ESG affects financial ratios (ROA), while for the other control variable, specifically, CSR does not affect. This can happen because companies that have made reports in a GRI manner must implement CSR in their implementation. This study proves that the greater the level of the GRI score will increase the profitability of ROA which reflects good financial performance. This research contributes to the fact that companies that have been registered in Indonesia should make GRI-based reports. The limitation of this research was this study uses all samples of companies in Indonesia that have implemented the GRI Guidelines with a limited sample (35 companies) and a limit of only 1 country with profitability scoring in rupiah (IDR) units and for further research. The suggestion is to use comparisons between countries (companies in South Asia or Worldwide) with use the exchange rate adjustment in US dollars for the measurement of ROA.

The implication of this research is useful for academics, providing a quantitative analysis of the Global Reporting Initiative (GRI), Return on Assets (ROA), especially for companies registered with IDX. For stakeholders, this research can provide information regarding the need for companies to report following the points of the GRI Guidelines so that the report becomes more comprehensive if environmental and social-based reports have been disclosed (disclosure) in detail that may increase investor confidence in conducting business transactions. For the public, this study provides information about the position of companies in Indonesia in conducting business transactions, especially in choosing transactions in finance such as buying or trading shares of companies that have implemented social and environmental aspects, because there are still limited large companies in Indonesia that have carried out detailed sustainability programs. and dominated by companies affiliated abroad. 


\section{REFERENCES}

Angelia, D., \& Suryaningsih, R. (2015). The Effect of Environmental Performance And Corporate Social Responsibility Disclosure Towards Financial Performance (Case Study to Manufacture, Infrastructure, And Service Companies That Listed At ISE (September),. Procedia - Social and Behavioral Sciences. 211,348-355. doi: https://doi.org/10.1016/j.sbspro.2015.11.045

Fleege, E., Adrian, E., (2004). The implementation of corporate ethics: a comparative study between Motorola and Ericsson. J. Undergrad, 7 (9).

Forte, A., (2013). Corporate Social Responsibility in the United States and Europe: How Important is it? The Future of Corporate Responsibility. International Business and Economics Journal, 12 (7), 815-824.

Fuente, J. A., \& García-s, I. M. (2017). The role of the board of directors in the adoption of GRI guidelines for the disclosure of CSR information, 141. Journal of Cleaner Production. 141, Pages 737-750. doi: https://doi.org/10.1016/j.jclepro.2016.09.155

Gamerschlag, R., Möller, K., \& Verbeeten, F. (2011). Determinants of voluntary CSR disclosure: empirical evidence from Germany. Review of Managerial Science, 5 (2), 233-262. https://doi.org/10.1007/s11846-010-0052-3

García-Sánchez, I. M., Frías-Aceituno, J. V., \& Rodríguez-Domínguez, L. (2013). Determinants of corporate social disclosure in Spanish local governments. Journal of Cleaner Production, 39, 60-72. https://doi.org/10.1016/j.jclepro.2012.08.037

Greening, D. W. (1994). Testing a model of organizational response to social and political issues. Academy of Management Journal, 37(3), 467-498.

GRI Standards. (2016). The Future Of Reporting Introducing the GRI Standards (Director: Buck \& Reinhardt). October 2016. GRI Standards International.

Lambooy, T., (2010). Institutionalization of Corporate Social Responsibility in the Corporate Governance Code: The New Trend of the Dutch Model. Emerald Group Publishing Limited.

Mishra, S., Suar, D., (2010). Does Corporate Social Responsibility Influence Firm Performance of Indian Companies?. Journal of Business Ethics, 95 (4), 571-601.

Oikonomou, I., Brooks, C., \& Pavelin, S. (2012). The impact of corporate social performance on financial risk and utility: A longitudinal analysis. Financial Management, 41(2), 483515.

Portney, P. R. (2008). The (not so) new corporate social responsibility: An empirical perspective. Review of Environmental Economics and Policy, 2, 261.

Sassen, R., Hinze, A.K., Hardeck, I., (2016). Impact of ESG factors on firm risk in Europe. J. Bus. Econ, Journal of Business Economics. 86 (867-904). Doi: http://dx.doi.org/10.1007/s11573-016-0819-3 
THE INFLUENCE OF VOLUNTARY GLOBAL REPORTING INITIATIVE (GRI) ON THE PERFORMANCE OF INDONESIA LISTED COMPANIES

Hurian Kamela dan Ryan Saputra Alam

Skare \& Golja, T. (2014). The impact of government CSR supporting policies on economic growth. Journal of Policy Modeling 36 (3) 562-577. Doi: https://doi.org/10.1016/j.jpolmod.2014.01.008

Syahnaz, Melisa. (2013). "Pengaruh Corporate Social Responsibility Terhadap Kinerja Keuangan Perusahaan Perbankan". Jurnal Ilmiah Mahasiswa FEB, 1(2).

Thomson Reuters (2020). Financial Datastream: Thomson Reuters Eikon Application. Limited Access : Universitas Indonesia. Online Access : July, 21-30 ${ }^{\text {th }}, 2020$. 